\title{
DANGEROUS SPORTS IN PANDEMIC TIMES. ANALISYS FOR CHILDREN'S PUBLIC SPORT UNITS OF ROMANIA
}

\author{
Andrei SIMION ${ }^{*}$, Doina CROITORU ${ }^{2}$ \\ ${ }^{1}$ Romanian Football Federation, Bucharest, Romania \\ ${ }^{2}$ National University of Physical Education and Sport, Faculty of Physical Education and Sport, Bucharest, \\ Romania \\ *Corresponding author: andrei.simi@gmail.com
}

DOI: https://doi.org/10.51267/icpesk2020bp14

\begin{abstract}
In our study, we categorised sports for which there are public sports clubs for children organized in Romania - School Sports Clubs and Classrooms with Sports Programme. These are financed from the state budget and local public administration. Training grounds, auxiliary spaces, materials, and facilities widely differ. With this in mind, we have only considered the dressing room as an interaction space between athletes. We consider that training and competition interactions are different, but in most sports, there is a risk to facilitate virus transmission - including SARS-CoV-2. The list of the 41 sports practised in children's public sports clubs was compiled. Private clubs were not included in the analysis, even though they had the same risk regarding virus transmission. For each sport, we considered the following dyadic interactions: athlete-athlete and athlete-coach, in both training and competitions, according to the rules of each sport. We also added the interactions between athletes in the dressing rooms and between athletes and match/competition officials (judge, referee etc.). Each interaction was subjectively graded with a number from 1 to $5: 1=$ low interaction, at least $5 \mathrm{~m}$ distance; $5=$ very close interaction, less than $1 \mathrm{~m}$ distance. The analysis showed that considering the current COVID-19 pandemic, organized sport is most of the time a dangerous environment for athletes, coaches, and officials, the most dangerous being the team sports. We believe that the current study might be of use in deciding which sports would be safer to "reopen" in the future.
\end{abstract}

Keywords: COVID-19, pandemic, dyadic interaction in sports.

\section{Introduction}

During the writing and research of this paper, our normal and regular lives were put on pause, much like the sports competitions in our country and throughout the world.

In the past, most papers approached topics related to the risks in sport. Most of the time, the risk of physical injury in sports: from acceptance through cultural habits (Nixon, 1993) to specific analyses of a certain sport (Vacca et al., 2020). To these, we can add lifestyle risks or using performance-enhancing drugs as constantly relevant topics.

The risk of injury is known and quantified for each sport by cohort studies (Nattiv et al., 1997). It is also, unfortunately, culturally accepted (Curry, 1993) and, most of the time, specialists, coaches and athletes take steps towards understanding and preventing injuries due to any cause (Bahr \& Krosshaug, 2005; Olsen et al., 2005; Fuller, 2007; Pelin et al., 2018). Most research shows that the prevalence of injury in major sports competitions is double that of illness. These illnesses are usually minor, like colds or stomach problems, but injuries are sometimes severe and can even interrupt an athlete's career.

The risk of contagion among athletes, sport officials and spectators has become a hot topic during the 2009 H1N1 influenza pandemic (Kim, 2010; Lim et al., 2010). The experience at 
the inaugural Asian Youth Games Singapore 2009 - mass gathering during a developing pandemic - was progressively forgotten.

Although it was approached scientifically, the authors were in a minority, and the danger was frequently ignored. Given that the prevalence of injuries is statistically superior to that of illnesses in big sports competitions, it did not receive the spotlight (Ruedl et al., 2012; Soligard et al., 2015; Engebretsen et al., 2013).

With previous threats such as the Zika virus being avoided, a state of ease in the world of sport has emerged (Petersen et al., 2016) and led to recommendations like "athletes should be target of annual influenza immunisation campaigns for two main reasons: i) because of the sharing of overcrowded environments and ii) because of the advantages of a healthy status for the performances" (Trabacchi et al., 2015, p. 183) to being ignored. Dorman (2000) has even highlighted that, for most of the infections considered, the athlete is more at-risk during activities off the playing field than while competing. The same author underlines that education rather than regulations is the most important part of activity in sport. A very recent paper shines further light on the topic: "They may grasp each other, touch each other, or touch equipment that other athletes have handled. They may breathe on one other in close proximity" (Francis \& Francis, 2020, p. 6).

The UEFA Champions League Round of 16 football matches in which Atalanta won against Valencia was considered to be an "incredible accelerator" in spreading COVID-19 (Martin, 2020). The match was held on February $19^{\text {th }}, 2020$, in San Siro Stadium in Milan, Italy, with an official attendance of 45,792. Home team won 4-1, which gave the home supporters plenty of reasons and occasions to hug and kiss. The first two cases of infection in Lithuania were due to contact with the Power Volley Milano team members during the 2019-20 CEV Challenge Cup matches held on 4 and 5 March at Saaremaa.

Although the main danger in big sports competitions is represented by the interaction between spectators, this is not a determining factor in youth and children's competitions in our country.

\section{Research question}

Considering the situation in which we all find ourselves - the COVID-19 pandemic, the question we ask is: how risky is the participation of young athletes in their practised sports? We are taking into account each sport available in School Sports Clubs (CSS) and High Schools with Sports Programme (LPS) or Classrooms with Sports Programme (CS) in Romania.

\section{Methodology}

The space-time coordination dynamic was studied by sports specialists as a way to analyse games and maximise performance (Erickson et al., 2011).

In a quick and very brief review of the papers that approach this topic, we can find research from basketball (Bourbousson et al., 2010), handball and squash (Fogtmann et al., 2011) and volleyball (Zetou et al., 2011).

The list of the 41 sports practised in children's public sports clubs (CSS and LPS) was compiled (Table 1). Private sports clubs were not included in the analysis, even though they 
were subject to the same COVID-19 risk. Information on more "exotic" sports for children in Romania was not available - golf, skateboarding, equitation.

From the three levels described by Shore (1994) - constitutive rules, procedural rules, and strategic plans, we eliminated strategic plans as they were very different from sport to sport and from one sport cluster to another.

For each sport, we analysed the interaction from a space-time point of view, in accordance with their official rules and regulations. The rules always specify the coach's location during the competition as well as when and how interaction with athletes is allowed - for support and/ or help, tips, indications, motivation. Also, we considered the same type of athlete-athlete and athlete-coach interactions in both training and competitions held according to the regulations of each sport. For the training part, we added the interactions between athletes in the dressing room, and for the competition part, we added the interactions between athletes and match/ competition officials (referees, judges etc). For training, we considered that the regulatory restrictions would not be respected, and the coach would usually stay very close to the athletes.

In Romania, sports programmes for children and juniors are developed in 42 educational institutions, as mentioned in the National Register of Sport Performance (Federația Sportului Școlar și Universitar [Federation of School and University Sport], 2018). These are School Sports Clubs (CSS) and High Schools with Sports Programme (LPS) or Classrooms with Sports Programme (CS) that are developed in different types of high schools. For the 2018-2019 competitive year, there were 12,049 children in the Performance groups (excluding novice and advanced groups). Of them, 9741 participated in official national competitions, and 974, in international competitions - some of them participating in both national and international competitions. 1113 athletes participated as members of national and Olympic teams. It is easily observed that these are children athletes who have participated in both national and international competitions.

Both independent School Sports Clubs and those functioning along with another educational unit are financed from the state budget and local public administration as well as from different sources according to Law no. 69 of Physical Education and Sport (Parlamentul României [Parliament of Romania], 2000). Due to this, financing may widely vary - there are units backed up by local communities and some sponsors, while others depend only on the state budget. Being linked to finances, training conditions across the country largely vary - some have very good conditions, while others are very much lacking in this department.

Training grounds, auxiliary spaces, materials, and other facilities differ considerably. There are some sports institutions that have a rich "heritage": training and competition halls, swimming pool, stadium, didactic establishments etc. Other sport institutions carry out their training and activity in spaces facilitated by the Ministry of National Education, regularly in schools and high schools. As such, in our analysis, we only took into account the dressing room as an interaction space between athletes.

For our study, we simplified the complexity of sport to some possible theoretical dyadic interactions: athletes-athlete, athlete-coach, athlete-competition official.

We have subjectively noted each possible dyadic interaction with a number from 1 to 5: 1 means low interaction (at least $5 \mathrm{~m}$ ), and 5 means very close interaction (less than $1 \mathrm{~m}$ ). Timeout interactions were included for team sports and sports played across halves, quarters, sets etc., the interactions between each of these being considered. 
For the athlete-athlete interaction, the socio-motor distance was taken into account - the shorter the distance, the higher the score.

The score was lowered if the sport was practised outdoors.

We have also considered that there are sports in which the athlete-athlete interaction differs according to the event. Different athletic events generate different interactions. In track and field, there are events where the athlete-athlete interaction is minimal (e.g. shot put or javelin throw). Rowing, kayaking-canoeing and yachting events can be individual or with differentlysized crews. In aerobic and rhythmic gymnastics, there are individual and team events. This is the reason why we could not grade certain sports more precisely.

For other sports such a wrestling, martial arts or boxing, the athlete-athlete interaction was graded the highest, as these sports involve physical contact and touch between athletes.

\section{Results}

Table 1. List of sports and interactions in training and competitions

\begin{tabular}{|c|c|c|c|c|c|c|c|}
\hline \multirow[b]{2}{*}{ Sport } & \multicolumn{3}{|c|}{ Competition } & \multirow[b]{2}{*}{ Sport } & \multicolumn{3}{|c|}{ Training } \\
\hline & $\begin{array}{l}\text { Athlete- } \\
\text { athlete } \\
\text { interaction }\end{array}$ & $\begin{array}{l}\text { Athlete- } \\
\text { coach } \\
\text { interaction }\end{array}$ & $\begin{array}{c}\text { Athlete- } \\
\text { competition } \\
\text { official } \\
\text { interaction } \\
\end{array}$ & & $\begin{array}{l}\text { Dressing } \\
\text { room }\end{array}$ & $\begin{array}{l}\text { Athlete- } \\
\text { athlete } \\
\text { interaction }\end{array}$ & $\begin{array}{l}\text { Athlete- } \\
\text { coach } \\
\text { interaction }\end{array}$ \\
\hline Martial arts & $\begin{array}{c}5 \\
1-3\end{array}$ & 5 & 4 & Martial arts & 5 & 5 & 5 \\
\hline Athletics & $\begin{array}{l}\text { depending } \\
\text { on the event }\end{array}$ & 1 & 1 & Athletics & 5 & 4 & 4 \\
\hline Badminton & 1 & 3 & 3 & Badminton & 5 & 4 & 4 \\
\hline Basketball & 5 & 5 & 5 & Basketball & 5 & 5 & 5 \\
\hline Baseball & 3 & 5 & 4 & Baseball & 5 & 5 & 5 \\
\hline Biathlon & 1 & 1 & 1 & Biathlon & 5 & 3 & 3 \\
\hline Boxing & $\begin{array}{c}5 \\
1-4\end{array}$ & 5 & 5 & Boxing & 5 & 5 & 5 \\
\hline Rowing & $\begin{array}{l}\text { depending } \\
\text { on crew }\end{array}$ & 1 & 1 & Rowing & 5 & 4 & 3 \\
\hline Bodybuilding & 1 & 1 & 1 & Bodybuilding & 5 & 5 & 3 \\
\hline Dancesport & 5 & 1 & 1 & Dancesport & 5 & 5 & 4 \\
\hline Football & 5 & 5 & 5 & Football & 5 & 5 & 5 \\
\hline $\begin{array}{l}\text { Aerobic } \\
\text { gymnastics }\end{array}$ & $\begin{array}{c}1-5 \\
\text { individual- } \\
\text { team }\end{array}$ & 3 & 1 & $\begin{array}{l}\text { Aerobic } \\
\text { gymnastics }\end{array}$ & 5 & 5 & 3 \\
\hline $\begin{array}{l}\text { Artistic } \\
\text { gymnastics }\end{array}$ & 1 & 4 & 1 & $\begin{array}{l}\text { Artistic } \\
\text { gymnastics }\end{array}$ & 5 & 5 & 5 \\
\hline $\begin{array}{l}\text { Rhythmic } \\
\text { gymnastics }\end{array}$ & $\begin{array}{c}1-5 \\
\text { individual- } \\
\text { team }\end{array}$ & 3 & 1 & $\begin{array}{l}\text { Rhythmic } \\
\text { gymnastics }\end{array}$ & 5 & 5 & 3 \\
\hline $\begin{array}{l}\text { Olympic } \\
\text { weightlifting }\end{array}$ & 1 & 5 & 1 & $\begin{array}{l}\text { Olympic } \\
\text { weightlifting }\end{array}$ & 5 & 3 & 3 \\
\hline Handball & 5 & 5 & 5 & Handball & 5 & 5 & 5 \\
\hline Ice hockey & 5 & 5 & 5 & Ice hockey & 5 & 5 & 5 \\
\hline Field hockey & 5 & 4 & 5 & Field hockey & 5 & 5 & 5 \\
\hline Swimming & 3 & 1 & 1 & Swimming & 5 & 4 & 3 \\
\hline Judo & 5 & 5 & 5 & Judo & 5 & 5 & 5 \\
\hline $\begin{array}{l}\text { Kayaking- } \\
\text { canoeing }\end{array}$ & $\begin{array}{c}1-4 \\
\text { depending } \\
\text { on crew }\end{array}$ & 1 & 1 & $\begin{array}{l}\text { Kayaking- } \\
\text { canoeing }\end{array}$ & 5 & 3 & 3 \\
\hline Karate & 5 & 5 & 5 & Karate & 5 & 5 & 5 \\
\hline $\begin{array}{l}\text { Wrestling } \\
\text { (freestyle, } \\
\text { Greco-Roman) }\end{array}$ & 5 & 5 & 5 & $\begin{array}{l}\text { Wrestling } \\
\text { (freestyle, } \\
\text { Greco-Roman) }\end{array}$ & 5 & 5 & 5 \\
\hline
\end{tabular}




\begin{tabular}{|c|c|c|c|c|c|c|c|}
\hline Ice skating & 2 & 2 & 1 & Ice skating & 5 & 3 & 3 \\
\hline Speed skating & 4 & 1 & 1 & Speed skating & 5 & 3 & 3 \\
\hline $\begin{array}{l}\text { Modern } \\
\text { pentathlon }\end{array}$ & 2 & 1 & 1 & $\begin{array}{l}\text { Modern } \\
\text { pentathlon }\end{array}$ & 5 & 5 & 3 \\
\hline Water polo & 2 & 5 & 3 & Water polo & 5 & 5 & 5 \\
\hline Rugby & 5 & 5 & 5 & Rugby & 5 & 5 & 5 \\
\hline Chess & 2 & 1 & 1 & Chess & 5 & 4 & 4 \\
\hline Luge & $\begin{array}{c}1-4 \\
\text { depending } \\
\text { on crew }\end{array}$ & 1 & 1 & Luge & 5 & 4 & 3 \\
\hline Diving & 1 & 1 & 1 & Diving & 5 & 3 & 4 \\
\hline Alpine skiing & 1 & 2 & 1 & Alpine skiing & 5 & 3 & 3 \\
\hline $\begin{array}{l}\text { Cross-country } \\
\text { skiing }\end{array}$ & 2 & 1 & 1 & $\begin{array}{l}\text { Cross-country } \\
\text { skiing }\end{array}$ & 5 & 3 & 3 \\
\hline Ski jumping & 1 & 2 & 1 & Ski jumping & 5 & 3 & 3 \\
\hline Fencing & 3 & 4 & 4 & Fencing & 5 & 4 & 4 \\
\hline Tennis & 1 & 1 & 1 & Tennis & 5 & 3 & 3 \\
\hline Table tennis & 1 & 3 & 1 & Table tennis & 5 & 3 & 3 \\
\hline Archery & 1 & 1 & 1 & Archery & 5 & 3 & 3 \\
\hline Shooting & 1 & 1 & 1 & Shooting & 5 & 3 & 3 \\
\hline Volleyball & $\begin{array}{c}5 \\
1-5\end{array}$ & 5 & 4 & Volleyball & 5 & 5 & 5 \\
\hline Yachting & $\begin{array}{l}\text { depending } \\
\text { on crew }\end{array}$ & 1 & 1 & Yachting & 5 & $1-5$ & 3 \\
\hline
\end{tabular}

\section{Conclusion}

During our analysis, we have not identified any sport that we could say is risk-free, especially considering the way in which children and youth players interact in sport. We do not include here the contagion risks that may appear while travelling from home to the training/ competition location because they are mostly irrelevant for the purpose of travel. Training sessions and training camps are wonderful opportunities for good child-child and child-adult interactions for those involved in sports, but in times of pandemic, each may become a vector of transmission.

As expected, we have not identified any sport in which there are no risks - in training or competition. Although we would be tempted to generalise that individual sports are less dangerous than team sports, we should not forget that athletes interact with each other in the dressing rooms, warm-up areas or resting spots and also use the same equipment.

Virus transmission-wise, the most dangerous are the team sports - the emergent dynamic patterns of the game, high interaction between athletes, coaches, and officials/referees, so a large number of people are involved. "Conceived as a dynamical system, team behaviour can also be regarded as an emergent process that results from the interaction between individual, environment and task constraints" (Travassos et al., 2010, p. 56). Starting from the highlights of these authors, we can say that, for a determined period of time, a determined number of officials, coaches, and athletes interact during a "fight" for a game object that passes from player to player and from hand to hand.

There are countless moments in a team sport match where athletes are in very close contact, much like in contact sports. We agree to consider team sports as "superorganisms" (Duarte et al., 2012, p. 633) in which we could identify multiple dyads that were analysed according to this concept.

Even in volleyball, where physical contact between opposing teams is almost non-existent, there are moments when athletes are in close proximity to each other - first-line players from 
both teams close to the net. Exchanges near the net bring the athletes so close together that they can practically feel each other's breaths, being separated by truly little space. We consider team sports but also boxing and combat sports as risky from this point of view, if not even more so, taking into account the actual number of people closely interacting with each other: coaches, teammates, opposing team, referees - for a prolonged period of time.

The safest sports in unsafe times would probably be athletics, skiing, individual rowing, or kayaking canoeing. We still do not know how the virus behaves in wet and humid environments like swimming pools.

The interaction between athletes and officials in competitions is vastly different - from judges to field referees. In most high-level sports for children, the match/competition officials include the referees - field referees, scorer, judges, line referees, time-keepers, starters. There are sports in which they are placed far from the athletes (rowing, skiing, tennis, gymnastics), but also sports in which referees share the same space with the athletes, with little space between them (boxing, wrestling, basketball, handball, football etc.)

We consider that, in team sports and combat sports, field referees have the same interactions as one athlete has with other athletes. Many times, they must be quite close to the place where the action is, ready to intervene between the teams. Referees/judges in sports where results are settled by marks or time are more sheltered, due to the distance between them and the athletes and coaches.

The interaction between athletes and coaches is inevitable in both training and competition. In competitions, time-outs and game breaks are classic examples of remarkably close space interaction during which coaches give instructions to their athletes.

We believe that, in training, the interaction between athlete and coach is higher than in competition, as coaches are on standby for athletes (gymnastics), are sparring partners (wrestling, boxing, karate) and offer 1 to 1 coaching. We cannot imagine a difficult exercise on the uneven bars in gymnastics without a coach ready to intervene and who does intervene in case of failure.

This type of interaction can be reduced. It will be difficult, but it can and will probably be a must in the near future. We still do not know how a grappling move will be demonstrated in contact sports, but sports professionals are inventive and adaptable.

We should not forget the place where most athlete-athlete interactions occur - the dressing room. More than "affiliation with peers" (McCarthy et al., 2008, p. 155), it is the traditional socialising area for both team and individual sports. If, in team sports, dressing rooms are divided by opposing teams, in individual sports, they are divided by gender. In the dressing room, the athletes prepare for the upcoming match - some of them have certain pre-match rituals, which is not rare in team sports. The dressing room is the place where the players and coach huddle up for their encouragement shout, where breaks from play are spent, the first part of a victory celebration is commenced, or where the defeated "treat their wounds". Because of the risk posed by the dressing room to become a vector of transmission, it may be even beneficial not to use it at all for a period after the restrictions are lifted, no matter how unpleasant this sort of measure may be.

The current analysis is incomplete as we could add, in the sum of all competition risk factors, the athlete-spectator distance considering certain sports that gather quite a big spectator crowd. In Romania, a large part of the crowd present at youth and children's competitions is formed 
by people who are close to young athletes - family members and friends, so, at this level, the total number of spectators is not that high, as opposed to senior competitions that can gather a rather significant crowd - thousands, if not tens of thousands. After the sports competitions reopen, the best thing, perhaps for a long period of time, would be to hold matches and meets behind closed doors, as the interaction of athletes with others might be closer and longer in the stands than on the playing field. Take, for instance, a football match in which fans sit closely together in the stands for at least 90 minutes, without considering half-time interactions, while contact between players on the pitch, although repeated, lasts for instances of seconds.

During competitions, the safest could be: tennis, shooting, archery, individual yachting (yachting is practised in only one CSS in Romania), biathlon, skiing, bodybuilding. Others might join the list if space-time athlete-athlete and athlete-coach interactions were reduced. In the case of children, it is difficult for them to socially distance themselves one from another in general but distancing themselves in the dressing room is highly improbable, if not impossible. Dressing-room size requirements also vary from one sport to another and, of course, the smaller the dressing room, the bigger the risk.

In the future, sports rules and regulations might and will probably be altered so that interaction is kept to a minimum during competitions. We believe that, for a long period, we will have to establish and respect a set of unwritten rules, no matter how difficult this may be. Until herd immunity is achieved, high-fives and victory hugs should be forgotten.

On a larger scale, one of the first sports competitions - for top performance seniors - we will see live on TV might be a tennis match, behind closed doors and with the number of people around the court reduced to a minimum. If it were winter, the best choice would be skiing - in any form. And it remains to be seen in the near future whether the economic factor outweighs the pandemic factor in the world of sports and in general. We are referring here to the implications of stopping sports competitions while looking at other aspects such as: suspending work contracts for professional athletes, postponing major sports competitions that would have brought significant economic benefits to host cities, media rights that are a very important source of revenue for competition organizers, federations or clubs.

In Romania (today, $2^{\text {nd }}$ May 2020), sports competitions and training sessions are interrupted (since $12^{\text {th }}$ March 2020) to limit the spread of COVID-19. We still do not know when training and competitions will resume normally. We are hoping that this analysis will help decisionmakers to choose the best options - in both selecting the date and adapting conditions to the dangers of transmitting the virus.

Finally, like Breivik (2011), we are asking: “And in how many risk sports?" (p. 319). Perhaps we should reformulate the definition: "A risk sport can be defined as an activity where there is a serious possibility of severe injury or death" (Brevik, 2011, p. 321).

All sports can be risk sports in the 2020 COVID-19 pandemic situation - at least until a large-scale population immunisation method is discovered. Regarding youth athletes, the decision to suspend training and competitions, as much unwanted as it is, is completely needed and welcome. 


\section{References}

Bahr, R., \& Krosshaug, T. (2005). Understanding injury mechanisms: A key component of preventing injuries in sport. British Journal of Sports Medicine, 39(6), 324-329. https://doi.org/10.1136/bjsm.2005.018341

Bourbousson, J., Sève, C., \& McGarry, T. (2010). Space-time coordination dynamics in basketball: Part 2. The interaction between the two teams. Journal of Sports Sciences, 28(3), 349-358. https://doi.org/10.1080/02640410903503640

Breivik, G. (2011). Dangerous play with the elements: Towards a phenomenology of risk sports. Sport, Ethics and Philosophy, 5(3), 314-330. https://doi.org/10.1080/17511321.2011.602585

Curry, T. J. (1993). A little pain never hurt anyone: Athletic career socialization and the normalization of sports injury. Symbolic Interaction, 16(3), 273-290. https://doi.org/10.1525/si.1993.16.3.273

Dorman, J. M. (2000). Contagious diseases in competitive sport: What are the risks? Journal of American College Health, 49(3), 105-109. https://doi.org/10.1080/07448480009596291

Duarte, R., Araújo, D., Correia, V., \& Davids, K. (2012). Sports teams as superorganisms. Sports Medicine, 42(8), 633-642. https://doi.org/10.1007/BF03262285

Engebretsen, L., Soligard, T., Steffen, K., Alonso, J. M., Aubry, M., Budgett, R., Dvorak, J., Jegathesan, M., Meeuwisse, W. H., Mountjoy, M., Palmer-Green, D., Vanhegan, I., \& Renström, P. A. (2013). Sports injuries and illnesses during the London Summer Olympic Games 2012. British Journal of Sports Medicine, 47(7), 407-414. https://doi.org/10.1136/bjsports-2013-092380

Erickson, K., Côté, J., Hollenstein, T., \& Deakin, J. (2011). Examining coach-athlete interactions using state space grids: An observational analysis in competitive youth sport. Psychology of Sport and Exercise, 12(6), 645-654. https://doi.org/10.1016/j.psychsport.2011.06.006

Federația Sportului Școlar și Universitar. (2018). Registrul național al performanțelor sportive: Anul școlar 2018-2019 [National register of sport performance: 2018-2019 School year]. https://fssu.ro/wp-content/uploads/2020/01/REGISTRU-Judetean-2018-2019.pdf

Fogtmann, M. H., Grønbæk, K., \& Ludvigsen, M. K. (2011). Interaction technology for collective and psychomotor training in sports. In Proceedings of the 8th International Conference on Advances in Computer Entertainment Technology, Lisbon, Portugal, 8-11 November 2011 (Vol. 13, pp. 1-8). Lisbon: Association for Computing Machinery. https://doi.org/10.1145/2071423.2071440

Francis, J., \& Francis, L. (2020). Immunization and participation in amateur youth sports. Journal of the Philosophy of Sport, 47(2), 151-167. https://doi.org/10.1080/00948705.2020.1750960

Fuller, C. W. (2007). Managing the risk of injury in sport. Clinical Journal of Sport Medicine, 17(3), 182-187. http://dx.doi.org/10.1097/JSM.0b013e31805930b0

Kim, W. J. (2010). Pandemic influenza (H1N1 2009): Experience and lessons. Infection \& Chemotherapy, 42(2), 61-63. https://doi.org/10.3947/ic.2010.42.2.61

Lim, H. C., Cutter, J., Lim, W. K., Ee, A., Wong, Y. C., \& Tay, B. K. (2010). The influenza A (H1N1-2009) experience at the inaugural Asian Youth Games Singapore 2009: Mass gathering during a developing pandemic. British Journal of Sports Medicine, 44(7), 528532. https://doi.org/10.1136/bjsm.2009.069831

Martin, W. (2020, March 26). Doctors say a 'biological bomb' Champions League football match in February was an 'incredible accelerator' for the coronavirus' deadly spread in northern Italy. Business Insider. https://www.businessinsider.nl/coronavirus-atalanta-vsvalencia-blamed-for-rapid-covid-19-spread-2020-3/ 
McCarthy, P. J., Jones, M. V., \& Clark-Carter, D. (2008). Understanding enjoyment in youth sport: A developmental perspective. Psychology of Sport and Exercise, 9(2), 142-156. https://doi.org/10.1016/j.psychsport.2007.01.005

Nattiv, A., Puffer, J. C., \& Green, G. A. (1997). Lifestyles and health risks of collegiate athletes: A multi-center study. Clinical Journal of Sport Medicine, 7(4), 262-272. https://doi.org/10.1097/00042752-199710000-00004

Nixon, H. L. (1993). Accepting the risks of pain and injury in sport: Mediated cultural influences on playing hurt. Sociology of Sport Journal, 10(2), 183-196. https://doi.org/10.1123/ssj.10.2.183

Olsen, O. E., Myklebust, G., Engebretsen, L., Holme, I., \& Bahr, R. (2005). Exercises to prevent lower limb injuries in youth sports: Cluster randomised controlled trial. BMJ, 330(7489): 449. https://doi.org/10.1136/bmj.38330.632801.8f

Parlamentul României. (2000, 28 aprilie). Legea nr. 69 a Educației Fizice și Sportului [Law no. 69 of Physical Education and Sport]. Monitorul Oficial, 200/16 mai 2000. http://legislatie.just.ro/Public/DetaliiDocument/22262

Pelin, F., Predoiu, R., Mitrache, G., Predoiu, A., \& Grigore, V. (2018). Generation of efficient behaviors in the case of performance athletes. Discobolul - Physical Education, Sport and Kinetotherapy Journal, 3(53), 31-38.

https://discobolulunefs.ro/wpcontent/uploads/2019/01/Discobolul_Nr_53_Septembrie2018.pdf

Petersen, E., Wilson, M. E., Touch, S., McCloskey, B., Mwaba, P., Bates, M., Dar, O., Mattes, F., Kidd, M., Ippolito, G., Azhar, E. I., \& Zumla, A. (2016). Rapid spread of Zika virus in the Americas - Implications for public health preparedness for mass gatherings at the 2016 Brazil Olympic Games. International Journal of Infectious Diseases, 44, 11-15. http://dx.doi.org/10.1016/j.ijid.2016.02.001

Ruedl, G., Schobersberger, W., Pocecco, E., Blank, C., Engebretsen, L., Soligard, T., Steffen, K., Kopp, M., \& Burtscher, M. (2012). Sport injuries and illnesses during the first Winter Youth Olympic Games 2012 in Innsbruck, Austria. British Journal of Sports Medicine, 46(15), 1030-1037. https://doi.org/10.1136/bjsports-2012-091534

Shore, B. (1994). Marginal play: Sport at the borderlands of time and space. International Review for the Sociology of Sport, 29(4), 349-365. https://doi.org/10.1177/101269029402900403

Soligard, T., Steffen, K., Palmer-Green, D., Aubry, M., Grant, M.-E., Meeuwisse, W, Mountjoy, M., Budgett, R., \& Engebretsen, L. (2015). Sports injuries and illnesses in the Sochi 2014 Olympic Winter Games. British Journal of Sports Medicine, 49(7). http://dx.doi.org/10.1136/bjsports-2014-094538

Trabacchi, V., Odone, A., Lillo, L., Pasquarella, C., \& Signorelli, C. (2015). Immunization practices in athletes. Acta Bio-Medica, 86(2), 181-188.

Travassos, B., Araújo, D., Correia, V., \& Esteves, P. (2010). Eco-dynamics approach to the study of team sports performance. The Open Sports Sciences Journal, 3(1), 56-57. http://dx.doi.org/10.2174/1875399X010030100056

Vacca, L., Rosso, V., \& Gastaldi, L. (2020). Risk assessment in different judo techniques for children and adolescent athletes. Proceedings of the Institution of Mechanical Engineers, Part H: Journal of Engineering in Medicine, 234(7), 686-696. https://doi.org/10.1177/0954411920915589

Zetou, E., Amprasi, E., Michalopoulou, M., \& Aggelousis, N. (2011). Volleyball coaches behavior assessment through systematic observation. Journal of Human Sport and Exercise, 6(4), 585-594. https://doi.org/10.4100/jhse.2011.64.02 